\title{
SYNTHESIS AND STRUCTURAL STUDIES OF FIRST ROW TRANSITION METAL COMPLEXES OF N-(2-NITRO)-BENZILIDINE-3-HYDRAZINO QUINOXALINE-2-ONE
}

\author{
P.V. Anantha Lakshmi ${ }^{1 *}$, P. Saritha Reddy ${ }^{1}$ and V. Jayatyaga Raju ${ }^{2}$ \\ ${ }^{1}$ Department of Chemistry, University College for Women, Osmania University, Koti, \\ Hyderabad-500001, Andhra Pradesh, India \\ ${ }^{2}$ Department of Chemistry, Addis Ababa University, P. O. Box 1176, Addis Ababa, Ethiopia
}

(Received November 20, 2007; revised March 22, 2008)

\begin{abstract}
Cr}$ (III), $\mathrm{Mn}$ (II), $\mathrm{Fe}$ (III), $\mathrm{Co}$ (II), Ni(II) and $\mathrm{Cu}$ (II) complexes of N-(2-nitro)-benzilidene-3-hydrazino quinoxaline-2-one (NBHQO) have been synthesized and characterized by elemental analysis, conductance, thermal, spectral and magnetic data. NBHQO acts as a bidentate ON donor in all the complexes except in $\mathrm{Ni}$ (II) complex in which it acts as a tridentate ONO donor. Octahedral geometries have been proposed for all the complexes except for $\mathrm{Cu}$ (II) complex to which the square planar geometry is assigned.
\end{abstract}

KEY WORDS: Metal complexes, N-(2-nitro)-benzilidene-3-hydrazino quinoxaline-2-one, ON donor

\section{INTRODUCTION}

Quinoxalines are a class of fused six membered heterocycles containing two nitrogens para to each other. Substituted quinoxalines have featured widely in anti microbial, pharmacological, pesticidal, insecticidal and herbicidal studies [1-3]. Metal complexes of quinoxaline derivatives, particularly those having azomethine centers of coordination have received less attention inspite of their potential metal binding properties and promising applicabilities $[4,5]$. Importance was hence given to studying these systems in our laboratories [6-8]. The preparation of N-(2-nitro)benzilidine-3-hydrazino quinoxaline-2-one (NBHQO) and its metal complexes has been undertaken in order to evaluate antimicrobial properties of these compounds. The present paper deals with the synthesis and characterization of NBHQO and its complexes with chromium(III), manganese(II), iron(III), cobalt(II), nickel(II) and copper(II).

\section{EXPERIMENTAL}

All the chemicals used were either of AR or chemically pure grade. Mass spectra were recorded on a Perkin-Elmer Hitachi-6L spectrometer and ${ }^{1} \mathrm{H}$ NMR spectra were recorded on a Varian XL$200 \mathrm{MHz}$ in DMSO-d 6 . IR spectra ( $\mathrm{KBr}$ discs) were recorded in the $4000-400 \mathrm{~cm}^{-1}$ region on a Schimadzu IR-435 and in Nujol media in the $4000-200 \mathrm{~cm}^{-1}$ region on a Perkin-Elmer 283-B spectrometer and electronic spectra of solids were recorded on a Cary-2390 UV-Vis-NIR spectrophotometer. The elemental analysis was carried out using a Heraus-CHN-rapid analyzer. Metal contents were estimated using an AAS Perkin Elmer-2380. Magnetic susceptibilities were measured on a Faraday balance (CAHN-7550-03 USA) at room temperature using $\mathrm{Hg}\left[\mathrm{Co}(\mathrm{NCS})_{4}\right]$ as calibrant. Diamagnetic correction using Pascal's constants and temperature independent paramagnetic corrections were computed [9]. The electrical conductance measurements were recorded using $10^{-3}$ molar solutions in DMSO with an Elico conductivity bridge (Model CM-180) and dip type cell calibrated with $\mathrm{KCl}$ solutions. DTA experiments were carried out using a Lead and Northup-USA instrument and TGA experiments were performed on a Perkin-Elmer model TGS-2 instrument. EPR were recorded on a Jeol SE-3X spectrometer at room temperature and at liquid nitrogen temperature.

*Corresponding author. E-mail: ananthaprasad2003@yahoo.co.in 
Synthesis of $N B H Q O$

NBHQO was prepared by a three-step process involving the synthesis of quinoxaline-2,3-dione [10] and 3-hydrazinoquinoxaline-2-one [11].

3-Hydrazinoquinoxaline-2-one $(8.8 \mathrm{~g})$ was dissolved in hot methanol $(150 \mathrm{~mL})$. A methanolic solution $(20 \mathrm{~mL})$ of 2-nitrobenzaldehyde $(2.6 \mathrm{~g})$ was added. The reaction mixture was refluxed for three hours. The dark yellow colored compound that separated out was filtered and washed with methanol and petroleum ether. The compound was recrystallised from methanol and dried in vacuum (Figure 1).

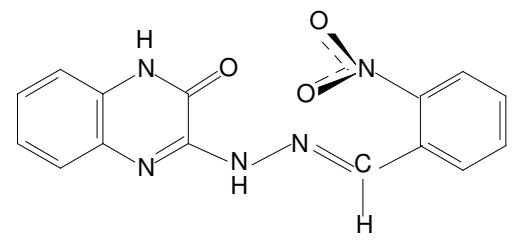

Figure 1. Structure of NBHQO.

Yield: 4.5 g, m.p. $>300{ }^{\circ} \mathrm{C}$. Anal. found: C 58.14; H 3.47; N 22.50; calcd. for $\mathrm{C}_{15} \mathrm{H}_{11} \mathrm{~N}_{5} \mathrm{O}_{2}$ : C 58.25; H 3.56; N 22.65 \%). [ $\left.\mathrm{M}^{+}\right] \mathrm{m} / \mathrm{z}$ 309. ${ }^{1} \mathrm{H}$ NMR (DMSO-d6) $\delta$ : 12.1 (ring $\mathrm{NH})$ (1), 7.1-8. (aromatic and $\mathrm{NH}$ of hydrazone fragment) [11], 9.0 (azomethine $\mathrm{CH}$ ) (1). IR bands $\left(\mathrm{cm}^{-1}\right)$ : $3300\left(v_{\mathrm{NH}}\right.$ of quinoxaline ring), $1680\left(\mathrm{v}_{\mathrm{C}=\mathrm{O}}\right), 1540\left(\mathrm{v}_{\mathrm{C}=\mathrm{N}}\right.$ free $), 1520\left(\mathrm{v}_{\mathrm{C}=\mathrm{N}}\right.$ ring $)$, $1560\left(v_{\mathrm{NO} 2}\right.$ asym), $1350\left(v_{\mathrm{NO} 2} \mathrm{sym}\right)$. UV-Vis $\left(\mathrm{cm}^{-1}\right): 43478$ (benzene moiety), $37037\left(\mathrm{NO}_{2}\right)$, 31250 (carbonyl), 23809, 22222 (free and ring azomethine).

Preparation of the complexes

A general method was adopted for the preparation of all the complexes. A methanolic suspension of the ligand was added in small increments to a methanolic solution of the metal chloride. After complete addition the metal to ligand mole ratio was always kept as 1:2. It was observed that the ligand dissolved completely in the presence of metal ion and a clear solution was obtained after each addition. The $\mathrm{pH}$ of the reaction mixture was then raised to 7 using a $1 \%$ alcoholic ammonia solution. The reaction mixture was refluxed for 3-4 $\mathrm{h}$. The colored product obtained was filtered hot and washed successively with small increments of methanol, petroleum ether and ether and dried in vacuo. The purity of ligand and metal complexes was checked by TLC using 1:1 ethyl acetate and methanol mixtures. The analytical data and proposed formulae for the complexes are given in Table 1.

\section{RESULTS AND DISCUSSION}

All the complexes are colored and stable in air. They are insoluble in common organic solvents but soluble in DMSO and DMF. They do not melt or decompose until $300{ }^{\circ} \mathrm{C}$. Analytical data indicate that the metal to ligand stoichiometry is $1: 2$ except in $\mathrm{Cu}$ (II) complex where in it is $1: 1$. $\mathrm{Cr}$ (III) and $\mathrm{Fe}(\mathrm{III})$ complexes are 1:1 electrolytes [12], Ni(II) complex is 1:2 electrolyte and $\mathrm{Mn}(\mathrm{II}), \mathrm{Co}(\mathrm{II}), \mathrm{Cu}$ (II) complexes are non-electrolytes (Table 1). From the elemental analysis and conductivities, it can be concluded that, in $\mathrm{Cr}$ (III) and $\mathrm{Fe}$ (III) complexes, out of three chlorides only one is ionisable while the other two are in the coordination sphere. It is also concluded that in $\mathrm{Mn}(\mathrm{II}), \mathrm{Co}(\mathrm{II}), \mathrm{Cu}(\mathrm{II})$ complexes two chloride ions are in a coordination sphere whereas in $\mathrm{Ni}$ (II) complex, two chloride ions are in an ionization sphere. The absence of coordinated water was established by TGA and DTA analysis. 
Table 1. Analytical data of metal complexes of NBHQO.

\begin{tabular}{|c|c|c|c|c|c|c|}
\hline \multirow{2}{*}{$\begin{array}{l}\text { Complexes } \\
\text { (molecular formula) }\end{array}$} & \multicolumn{5}{|c|}{ Calcd. (found) $\%$} & \multirow{2}{*}{ 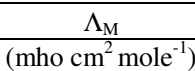 } \\
\hline & Metal & Carbon & Hydrogen & Nitrogen & Chloride & \\
\hline $\begin{array}{l}{\left[\mathrm{Cr}(\mathrm{NBHQO})_{2} \mathrm{Cl}_{2}\right] \mathrm{Cl}} \\
\left(\mathrm{CrC}_{30} \mathrm{H}_{22} \mathrm{~N}_{10} \mathrm{O}_{6} \mathrm{Cl}_{3}\right)\end{array}$ & $\begin{array}{c}6.83 \\
(6.71)\end{array}$ & $\begin{array}{c}46.36 \\
(45.18)\end{array}$ & $\begin{array}{c}2.83 \\
(2.79)\end{array}$ & $\begin{array}{c}18.02 \\
(18.56)\end{array}$ & $\begin{array}{c}13.89 \\
(13.64)\end{array}$ & 72 \\
\hline $\begin{array}{l}{\left[\mathrm{Mn}(\mathrm{NBHQO})_{2} \mathrm{Cl}_{2}\right]} \\
\left(\mathrm{MnC}_{30} \mathrm{H}_{22} \mathrm{~N}_{10} \mathrm{O}_{6} \mathrm{Cl}_{2}\right)\end{array}$ & $\begin{array}{c}7.39 \\
(7.05)\end{array}$ & $\begin{array}{c}48.38 \\
(47.42)\end{array}$ & $\begin{array}{l}2.95 \\
(2.89)\end{array}$ & $\begin{array}{c}18.81 \\
(17.41)\end{array}$ & $\begin{array}{c}9.54 \\
(9.36)\end{array}$ & 17 \\
\hline $\begin{array}{l}{\left[\mathrm{Fe}(\mathrm{NBHQO})_{2} \mathrm{Cl}_{2}\right] \mathrm{Cl}} \\
\left(\mathrm{FeC}_{30} \mathrm{H}_{22} \mathrm{~N}_{10} \mathrm{O}_{6} \mathrm{Cl}_{3}\right)\end{array}$ & $\begin{array}{c}7.17 \\
(7.08)\end{array}$ & $\begin{array}{l}46.12 \\
(45.34)\end{array}$ & $\begin{array}{c}2.82 \\
(2.75)\end{array}$ & $\begin{array}{c}17.94 \\
(17.67)\end{array}$ & $\begin{array}{c}13.65 \\
(13.41)\end{array}$ & 67 \\
\hline $\begin{array}{l}{\left[\mathrm{Co}(\mathrm{NBHQO}){ }_{2} \mathrm{Cl}_{2}\right]} \\
\left(\mathrm{CoC}_{30} \mathrm{H}_{22} \mathrm{~N}_{10} \mathrm{O}_{6} \mathrm{Cl}_{2}\right)\end{array}$ & $\begin{array}{c}7.88 \\
(7.81)\end{array}$ & $\begin{array}{l}48.12 \\
(46.53)\end{array}$ & $\begin{array}{c}2.94 \\
(2.93)\end{array}$ & $\begin{array}{c}18.71 \\
(18.50)\end{array}$ & $\begin{array}{c}9.49 \\
(9.33)\end{array}$ & 15 \\
\hline $\begin{array}{l}{[\mathrm{Ni}(\mathrm{NBHQO})] \mathrm{Cl}_{2}} \\
\left(\mathrm{NiC}_{30} \mathrm{H}_{22} \mathrm{~N}_{10} \mathrm{O}_{6} \mathrm{Cl}_{2}\right)\end{array}$ & $\begin{array}{c}7.88 \\
(7.79)\end{array}$ & $\begin{array}{l}48.12 \\
(46.53)\end{array}$ & $\begin{array}{c}2.94 \\
(2.91) \\
\end{array}$ & $\begin{array}{c}18.71 \\
(18.27)\end{array}$ & $\begin{array}{c}9.49 \\
(9.28) \\
\end{array}$ & 125 \\
\hline $\begin{array}{l}{\left[\mathrm{Cu}(\mathrm{NBHQO}) \mathrm{Cl}_{2}\right]} \\
\left(\mathrm{CuC}_{15} \mathrm{H}_{11} \mathrm{~N}_{5} \mathrm{O}_{3} \mathrm{Cl}_{2}\right)\end{array}$ & $\begin{array}{c}14.38 \\
(14.20)\end{array}$ & $\begin{array}{l}40.45 \\
(40.23)\end{array}$ & $\begin{array}{c}2.47 \\
(2.41)\end{array}$ & $\begin{array}{c}15.73 \\
(15.56)\end{array}$ & $\begin{array}{c}15.99 \\
(15.71)\end{array}$ & 16 \\
\hline
\end{tabular}

IR spectra

IR spectral data of the complexes are given in Table 2. The $v_{\mathrm{C}=\mathrm{N}}$ (free) in all the complexes has undergone a downward shift by about $20 \mathrm{~cm}^{-1}$, merging with the $\mathrm{v}_{\mathrm{C}=\mathrm{N}}$ (ring), concluding that the nitrogen of azomethine (free) is participating in M-L bonding in these complexes [13]. In all the complexes an upward shift of $\mathrm{v}_{\mathrm{NO} 2}$ (sym) by about $20 \mathrm{~cm}^{-1}$ and a downward shift of $\mathrm{v}_{\mathrm{NO} 2}$ (asym) by about $10-20 \mathrm{~cm}^{-1}$ indicate the binding of $-\mathrm{NO}_{2}$ group through its oxygen atom [14]. The absence of sharp peak at $600 \mathrm{~cm}^{-1}$, corresponding to the $\mathrm{NO}_{2}$ wagging mode of the ligand, further confirms the coordination of one of the oxygens of $-\mathrm{NO}_{2}$ [14] which is characteristic of unidentate oxygen bonded nitrite mode. In nickel(II) complex, the downward shift of $\mathrm{v}_{\mathrm{C}=\mathrm{O}}$ confirms the participation of carbonyl oxygen in coordination [15]. These observations show that the ligand behaves as a neutral bidentate ON donor towards all metal ions except towards nickel(II) ion where it behaves as neutral tridentate ONO donor. The new bands in the far IR region are attributed to $v(\mathrm{M}-\mathrm{O}), v(\mathrm{M}-\mathrm{N}), v(\mathrm{M}-\mathrm{Cl})[16,17]$. Absence of a band in the 330-300 $\mathrm{cm}^{-1}$ region in nickel(II) complex indicates the absence of a $\mathrm{M}-\mathrm{Cl}$ bond.

Table 2. Characteristic infrared frequencies of complexes of NBHQO $\left(\mathrm{cm}^{-1}\right)$.

\begin{tabular}{|c|c|c|c|c|c|c|c|c|}
\hline Compound & $\mathrm{V}_{\mathrm{N}-\mathrm{H}}$ & $\begin{array}{l}\mathrm{V}_{\mathrm{N}-\mathrm{H}} \\
\text { (ring) }\end{array}$ & $v_{\mathrm{C}=\mathrm{O}}$ & $\begin{array}{l}v_{C=N} \\
\text { (free) }\end{array}$ & $\begin{array}{r}v_{\mathrm{C}=\mathrm{N}} \\
\text { (ring) }\end{array}$ & $v_{\mathrm{NO} 2}$ & $\mathrm{v}_{\mathrm{NO} 2}$ & New Bands \\
\hline NBHQO & 3300 & $\begin{array}{l}2950- \\
2850\end{array}$ & 1674 & 1540 & 1520 & 1560 & 1350 & \\
\hline Cr(III) complex & 3300 & 2950 & 1680 & \multicolumn{2}{|c|}{1520} & 1570 & 1340 & $580,560,450,430,350$ \\
\hline Mn(II) complex & 3300 & 3000 & 1680 & \multicolumn{2}{|c|}{1517} & 1577 & 1340 & $478,456,430,315$ \\
\hline Fe(III) complex & 3300 & 2950 & 1680 & \multicolumn{2}{|c|}{1510} & 1570 & 1340 & $560,540,480,350$ \\
\hline $\mathrm{Co}$ (II) complex & 3300 & 2950 & 1680 & \multicolumn{2}{|c|}{1510} & 1570 & 1330 & $580,530,510,470,320$ \\
\hline $\mathrm{Ni}(\mathrm{II})$ complex & 3300 & 3000 & 1660 & \multicolumn{2}{|c|}{1510} & 1580 & 1340 & $580,560,540,520,480,460$ \\
\hline $\mathrm{Cu}(\mathrm{II})$ complex & 3300 & 3000 & 1680 & \multicolumn{2}{|c|}{1510} & 1580 & 1340 & $620,570,530,490,350$ \\
\hline
\end{tabular}

It is of interest to note that this ligand may exercise several possible modes of coordination. (1) It can be a neutral bidentate ON donor, using carbonyl oxygen and exocyclic nitrogen as coordinating centers to form 5-membered chelates. (2) It can also be a neutral bidentate $\mathrm{ON}$ donor, while employing carbonyl oxygen and azomethine (the other $\mathrm{C}=\mathrm{N}$ ) nitrogen in coordination to form 6-membered chelates. In both cases, the chelates will have only two pairs of conjugated pi electrons in the absence of metal-ligand pi interaction. (3) It can be again a 
neutral ON donor, with azomethine nitrogen and oxygen of the nitro group involved in coordination to form 7-membered metal chelates. This mode has three pairs of pi electrons in the chelate, which are probably the driving force for its preference in several of these complexes. With this kind of conjugation possible, we believe that the planarity of the chelate is also protected. We feel that this is the deciding factor in stabilizing these complexes. (4) the ligand can also act as an $\mathrm{ONO}$ donor, while additionally involving the carbonyl oxygen along with the ON centers as in mode (3). This can make a combination of six and seven membered chelation. The preference of this mode may be under the influence of additional steric and electronic factors and also the metal ion radius. A Ni(II) ion seems to satisfy this requirement, as distinctly observed from the data.

\section{Magnetic moments and electronic spectral data}

The room temperature magnetic moments and electronic spectral data are given in Table 3 . The former data reflect the paramagnetic nature of all the complexes. These values are consistent with a spin free configuration. The absorption maxima for the complexes and the corresponding assignments of the electronic transitions are also included in Table 3. On the basis of the data octahedral geometries have been proposed except for the copper(II) complex in which the assignments are in agreement with square planar geometry. In the nickel(II) complex the inter electronic repulsion parameters (B) and nephelauxetic parameter $(\beta)$ are evaluated as 619.9 and 0.574 , respectively, which indicate a moderate field strength experienced by the metal ion due to the tridentate nature of ligand [18].

Table 3. Magnetic and electronic spectral data of complexes.

\begin{tabular}{|l|l|l|l|}
\hline Complex & $\mu_{\text {eff }}(\mathrm{BM})$ & Band position $\left(\mathrm{cm}^{-1}\right)$ & Assignment \\
\hline $\mathrm{Cr}(\mathrm{III})$ & 3.82 & 32258 & ${ }^{4} \mathrm{~A}_{2 \mathrm{~g}} \rightarrow{ }^{4} \mathrm{~T}_{2 \mathrm{~g}}$ \\
& & 19607 & ${ }^{4} \mathrm{~A}_{2 \mathrm{~g}} \rightarrow{ }^{4} \mathrm{~T}_{1 \mathrm{~g}}$ \\
& & 15384 & ${ }^{4} \mathrm{~A}_{2 \mathrm{~g}} \rightarrow{ }^{4} \mathrm{~T}_{1 \mathrm{~g}}(\mathrm{P})$ \\
\hline $\mathrm{Mn}$ (II) & 5.92 & $26315-11494$ & - \\
\hline $\mathrm{Fe}$ (III) & 5.8 & $25000-16000$ & - \\
\hline $\mathrm{Co}$ (II) & 4.0 & 20408 & \multicolumn{1}{c|}{} \\
& & 15873 & ${ }^{4} \mathrm{~T}_{1 \mathrm{~g}} \rightarrow{ }^{4} \mathrm{~T}_{1 \mathrm{~g}}(\mathrm{P})$ \\
& & 8771 & ${ }^{4} \mathrm{~T}_{1 \mathrm{~g}} \rightarrow{ }^{4} \mathrm{~A}_{2 \mathrm{~g}}$ \\
$\mathrm{Ni}(\mathrm{II})$ & 3.12 & 20000 & ${ }^{4} \mathrm{~T}_{1 \mathrm{~g}} \rightarrow{ }^{4} \mathrm{~T}_{2 \mathrm{~g}}$ \\
& & 15384 & ${ }^{3} \mathrm{~A}_{2 \mathrm{~g}} \rightarrow{ }^{3} \mathrm{~T}_{1 \mathrm{~g}}(\mathrm{P})$ \\
& & 8695 & ${ }^{3} \mathrm{~A}_{2 \mathrm{~g}} \rightarrow{ }^{3} \mathrm{~T}_{1 \mathrm{~g}}(\mathrm{~F})$ \\
\hline $\mathrm{Cu}$ (II) & 1.96 & 24390 & ${ }^{3} \mathrm{~A}_{2 \mathrm{~g}} \rightarrow{ }^{3} \mathrm{~T}_{2 \mathrm{~g}}$ \\
& & 20000 & ${ }^{2} \mathrm{~B}_{1 \mathrm{~g}} \rightarrow{ }^{2} \mathrm{~B}_{2 \mathrm{~g}}$ \\
& & 17543 & ${ }^{2} \mathrm{~B}_{2 \mathrm{~g}} \rightarrow{ }^{2} \mathrm{~A}_{1 \mathrm{~g}}$ \\
& & & ${ }^{2} \mathrm{~B}_{2 \mathrm{~g}} \rightarrow{ }^{2} \mathrm{E}_{\mathrm{g}}$ \\
\hline
\end{tabular}

\section{EPR spectrum of copper(II) complex}

The EPR spectrum of copper(II) complex at liquid nitrogen temperature has been evaluated to give $g_{x x}, g_{y y}, g_{z z}$ and $g_{a v}$ values as 2.0502, 2.0839, 2.2840 and 2.139, respectively. The $g$ tensor of the complex exhibits nearly rhombic symmetry. These observations support the square planar geometry of this complex [19].

\section{Antimicrobial activity}

Preliminary studies on the bactericidal properties of ligand NBHQO and its metal complexes indicate promising activity against Staphylococcus aureus. Detailed studies are in progress. 


\section{CONCLUSIONS}

Two distinct patterns of metal binding by the ligand NBHQO are noted. It acts as a ON donor in all the complexes, coordinating through one of the azomethine nitrogens and oxygen of nitro group, except in nickel(II) complex in which a carbonyl oxygen is also taking part in coordination so that the ligand acts a tridentate ONO donor.

On the basis of analytical, thermal, conductivity, magnetic and spectral data, octahedral geometries have been proposed for all the complexes except for copper(II) complex to which the square planar geometry is assigned (Figure 2, 3 and 4).

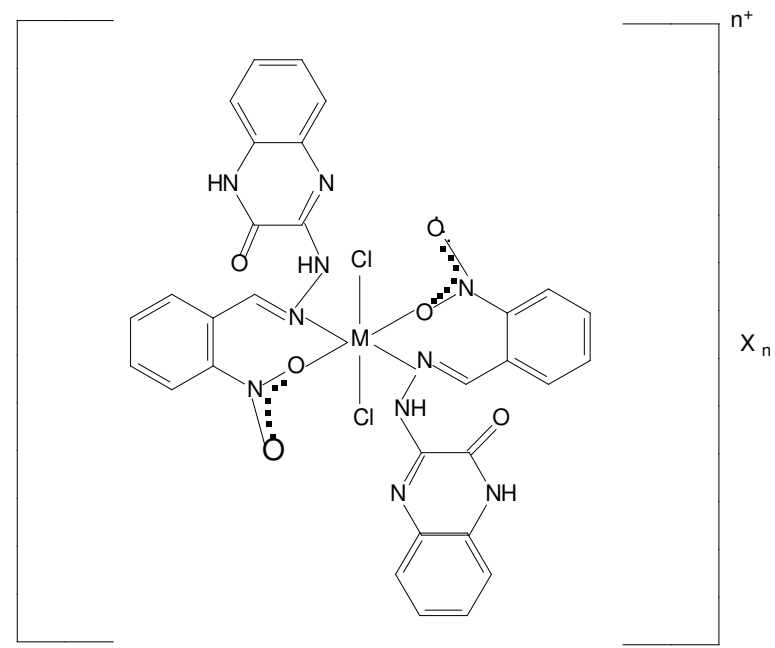

Figure 2. $\mathrm{M}=\mathrm{Cr}(\mathrm{III}), \mathrm{Fe}(\mathrm{III}), \mathrm{X}=\mathrm{Cl}^{-}, \mathrm{n}=1 ; \mathrm{M}=\mathrm{Mn}(\mathrm{II}), \mathrm{Co}(\mathrm{II}), \mathrm{X}=\mathrm{Cl}^{-}, \mathrm{n}=0$.
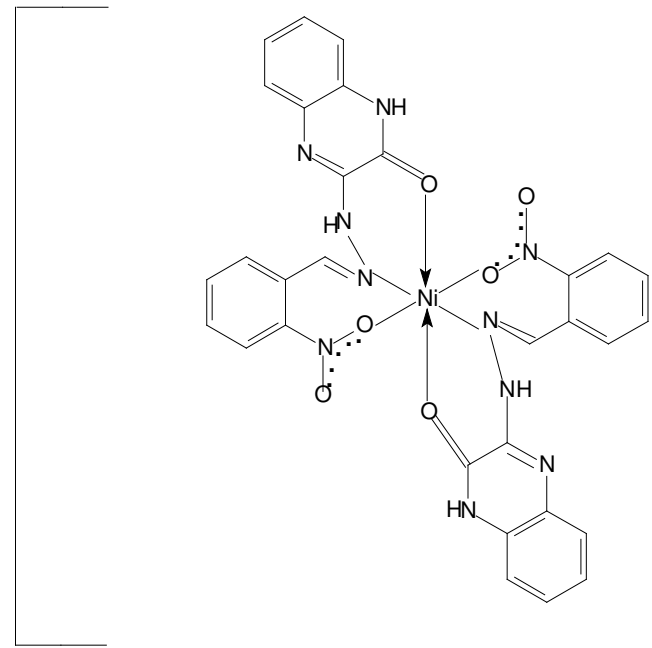

Figure 3. Ni(II) complex.

Bull. Chem. Soc. Ethiop. 2008, 22(3) 


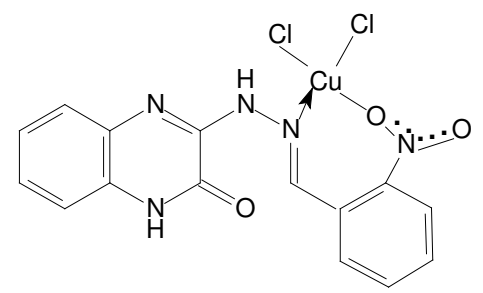

Figure 4. $\mathrm{Cu}(\mathrm{II})$ complex.

\section{REFERENCES}

1. Schenfelder, D.; Slumm, G.; Bohla, M.; Niclas, J. Pharmazie 1988, 43, 837.

2. Fabio Paul, F.; Lang, S.A.; Yang, L.; Cufcik, T.; Andrew, S. J. Med. Chem. 1980, 23, 201.

3. Sasse, K.; Wegle, R.; Unterslenhoefer, G.; Grews, F. Angew. Chem. 1960, 72, 973.

4. Dianzhong, F.; Wang, M.; Wang, B. Polyhedron 1992, 11, 1109.

5. Dianzhong, F.; Yukin, Z.; Wang, V. Polyhedron 1992, 11, 1113.

6. Rani, D.S.; Lakshmi, P.V.A.; Jayatyagaraju, V. Trans. Met. Chem. 1994, 19, 75.

7. Ananthalakshmi, P.V.; Sandhyarani, D.; Jayatyagaraju, V. Asian J. Chem. 1995, 7, 296.

8. Sandhyarani, D.; Jayatyagaraju, V.; Ananthalakshmi, P.V. Indian J. Chem. 1999, 38A, 385.

9. Figgis, B.N.; Lewis, J.; Modern Coordination Chemistry, Interscience: New York; 1960.

10. Philips, J. Chem. Soc. (C) 1928, 2397.

11. Cheeseman, G.W.H.; Rafiq, M. J. Chem. Soc. (C) 1971, 453.

12. Angelici, R.J. Synthesis and Technique in Inorganic Chemistry, Saunders: Philadelphia; 1969.

13. Pouralimardan, O.; Chamayou, A.C.; Janiak, C.; Monfared, H.H. Inorg. Chim. Acta 2007, 360, 1599.

14. Nakamoto, K. Infrared Spectra of Inorganic and Coordination Compounds, Wiley Interscience: New York; 1970.

15. Shyamala, B.S.; Ananthalakshmi, P.V.; Raju, V.J.T.; Nagarajarao, P.; Reddy, P.U.M. Biometals 1992, 5, 23.

16. Getivaetal, V.T. Cent. Eur. J. Chem. 2007, 5, 118.

17. Lider, E.V. Russ. J. Coord. Chem. 2007, 33, 37.

18. Mehta, P.; Gahlot, A.; Mehta, R.K. J. Indian Chem. Soc. 1987, 64, 137.

19. Shirini, Z.; Mukherjee, R.M. Polyhedron 1992, 11, 2625. 